\title{
Distribution of extracellular polymeric substances in aerobic granules
}

\author{
M. Y. Chen • D. J. Lee $\cdot$ J. H. Tay
}

Received: 8 April 2006 /Revised: 11 July 2006 / Accepted: 8 August 2006/ Published online: 7 October 2006

(C) Springer-Verlag 2006

\begin{abstract}
Extracellular matrix provides an architectural structure and mechanical stability for aerobic granules. Distributions of cells and extracellular polymeric substances (EPS), including proteins, $\alpha$ - and $\beta$-D-glucopyranose polysaccharides, in acetate-fed granules and phenol-fed granules were probed using a novel quadruple staining scheme. In acetate-fed granules, protein and $\beta$-D-glucopyranose polysaccharides formed the core, whereas, the cells and $\alpha$-D-glucopyranose polysaccharides accumulated in the granule outer layers. Based on these experimental findings, this study indicated that different conclusions can be obtained regarding EPS distributions when granules were stained differently. The core of phenol-fed granules, conversely, was formed principally by proteins; whereas, the cells and $\alpha$ - and $\beta$-D-glucopyranose polysaccharides were accumulated at an outer filamentous layer. Using a series of confocal laser scanning microscope (CLSM) images whose threshold values were determined via Otsu's scheme, the three-dimensional distributions of cells and EPS were produced using a polygonal surface model. Structural information extracted can be applied in further development of comprehensive granule models.
\end{abstract}

M. Y. Chen • D. J. Lee $(\square)$

Department of Chemical Engineering,

National Taiwan University,

Taipei 10617, Taiwan

e-mail: djlee@ntu.edu.tw

\section{J. H. Tay}

Environmental Engineering Research Centre,

School of Civil and Environmental Engineering,

Nanyang Technological University,

50 Nanyang Ave.,

Singapore 639798, Singapore
Keywords Aerobic granule · EPS · Staining · Structure · Model

\section{Introduction}

The aerobic granule process has been extensively investigated (Morgenroth et al. 1997; Beun et al. 1999; Peng et al. 1999; Tay et al. 2001a; Yang et al. 2003; Liu and Tay 2004; Chiu et al. 2006). Due to their density, granules typically settle fast in water pools (Liu and Tay 2004). Long-term stability of granules in aerated basins remains a concern for possible wide field applications of aerobic granule processes (Liu and Liu 2006).

Tay et al. (2001b) reported that increased aeration, yielding high shear stress on granules, results in increased polysaccharide formation, whose loss would cause disintegration of the granule. Later, Wang et al. (2005) utilized calcofluor white to stain $\beta$-linked D-glucopyranose polysaccharides in their acetate-fed granules. They noted a granule core full of loosely structured substances surrounded by $\beta$-D-glucopyranose polysaccharides in a dense, outer layer with a thickness of $200-300 \mu \mathrm{m}$ to ensure the structural stability of the granules.

McSwain et al. (2005) noted that their glucose and peptone fed granules contained 6.4-10.9 times more protein than carbohydrates. Furthermore, they fluorescently stained the granules using fluorescein-isothiocyanate (FITC), concanavalin A (Con A) lectin conjugates, and SYTO 63, to probe in situ the corresponding content distributions of proteins, $\alpha$-D-glucopyranose polysaccharides and cells, respectively. They observed that the cells and $\alpha$-D-glucopyranose polysaccharide accumulated in an outer layer of the granules, while the protein constituted the core of the granules. Accordingly, the authors of that investigation 
claimed that the noncellular, protein core stabilized the aerobic granule structure.

The above discussion demonstrates that the distribution of extracellular polymeric substances (EPS) in glucose or acetate-fed aerobic granules remains unclear. The main reason for this noted discrepancy is the absence of a suitable staining scheme for probing simultaneously all of the constituents of interest on a single granule. Table 1 presents the related studies that utilize stains to probe nucleic acids and/or other EPS in "bio-aggregates." Though stained biofilm systems have been intensively investigated, the investigations of stained granules are comparably rare. Additionally, existing studies have applied up to three stains to the same bio-aggregates for observation. Structural differences can be substantial among individual granules collected from the same wastewater sample. A staining scheme for the same bio-aggregate with more than three stains is highly desirable to acquiring detailed information on how EPS is distributed in the same bio-aggregate and minimize possible bias.
The extracellular matrix provides an architectural structure and mechanical stability for aerobic granules. Understanding the detailed structure of the matrix is the step toward comprehensive modeling of complex transport/ reaction processes in the granules. The current work has three principal goals. First, a novel quadruple staining scheme is presented to evaluate the distributions of cells (nucleic acids) and EPS (proteins, $\alpha$ - and $\beta$-D-glucopyranose polysaccharides) in granules. Second, this scheme is applied to an acetate-fed granule to demonstrate how different conclusions regarding EPS distributions over granule interiors can be acquired when the granules are stained differently. The EPS in phenol-fed granules are stained using the proposed quadruple staining approach to identify the different distribution patterns of EPS when the granules are stressed by phenol. Third, this study demonstrates the use of an image processing scheme to build the three-dimensional polygonal surface models for cells and EPS in the granule. This structural information can be

Table 1 Literature works using stains for probing EPS in bio-aggregates

\begin{tabular}{|c|c|c|c|}
\hline Reference & Sample & Stain(s) & $N_{\mathrm{S}}^{\mathrm{a}}$ \\
\hline deBeer et al. (1996) & Granule/floc & Calcofluor white & 1 \\
\hline Neu et al. (2001) & biofilm & Lectins & 1 \\
\hline Strathmann et al. (2002) & Biofilm & Lectins & 1 \\
\hline Strathmann et al. (2002) & Biofilm & SYTO 9, TRITC-lectin & 2 \\
\hline Bockelmann et al. (2002) & River snow & SYTO 9, T. vulgaris TRITC-lectin & 2 \\
\hline Bockelmann et al. (2002) & River snow & FISH, lectins & 2 \\
\hline Bockelmann et al. (2002) & River snow & DAPI and $P$. aeruginosa FITC-lectin & 2 \\
\hline Bockelmann et al. (2002) & Biofilm & SYTO 60 , Aleuria aurantia lectin & 2 \\
\hline Schmid et al. (2003) & Floc & FITC & 1 \\
\hline Lawrence et al. (2003) & Biofilm & SyproOrange, Syto9, Nile Red & 3 \\
\hline Lawrence et al. (2003) & Biofilm & SyproOrange, Syto9, s elected lectins & 3 \\
\hline Lawrence et al. (2003) & Biofilm & Nile Red, Syto9, selected lectins & 2 \\
\hline Lawrence et al. (2003) & Biofilm & Nile Red, SyproOrange, selected lectins & 2 \\
\hline Lawrence et al. (2003) & Biofilm & Syto9, selected lectins & 2 \\
\hline Lawrence et al. (2004) & Biofilm & SYTO 9, Triticum vulgaris-TRITC, autofluorescence & 3 \\
\hline Lawrence et al. (2004) & Biofilm & Lectins & 1 \\
\hline Lawrence et al. (2004) & Biofilm & BacLight Live-Dead staining kit & 2 \\
\hline Boessmann et al. (2004) & biofilm & SYTO 60 & 1 \\
\hline Boessmann et al. (2004) & Biofilm & Aleuria aurantia lectin-Alexa 488 & 1 \\
\hline Staudt et al. (2004) & Biofilm & SYTO 60 and Aleuria aurantia lectin & 1 \\
\hline Neu et al. (2004) & Biofilm & SYTO 9, SYTO 40, Autofluorescence & 3 \\
\hline Neu et al. (2004) & Biofilm & Lectins & 2 \\
\hline Cerca et al. (2005) & Biofilm & Wheat germ agglutinin and bacterial stain & 2 \\
\hline Lawrence et al. (2005) & Biofilm & SYTO 9, Triticum vulgaris-TRITC, autofluorescence & 3 \\
\hline Lawrence et al. (2005) & Biofilm & Live-Dead BacLight staining kit & 2 \\
\hline Lawrence et al. (2005) & Biofilm & Lectins & 1 \\
\hline McSwain et al. (2005) & Granule & Syto 63, FITC, Con A & 3 \\
\hline Wang et al. (2005) & Granule & ConA-FITC & 1 \\
\hline Wang et al. (2005) & Granule & BacLight Live/Dead staining kit & 2 \\
\hline
\end{tabular}

${ }^{\mathrm{a}} N_{\mathrm{s}}$ Number of stains applied on the same bio-aggregate 
applied in further development of comprehensive granule models.

\section{Experimental}

The acetate-fed granules were incubated for 3 weeks in a column-type sequential aerobic sludge blanket reactor with a working volume of 2.51 . The reactor was fed with the seed sludge collected from return sludge stream of a municipal wastewater treatment plant in Taipei and an acetate-based synthetic wastewater with mineral concentrations, the same as those used by Chiu et al. (2006). This synthetic wastewater contained acetate as the sole carbon source and a substrate concentration equivalent to $1,000 \mathrm{mg}$ $1^{-1}$ COD. Fine air bubbles for aeration and mixing were supplied through a dispenser at the bottom of the reactor at a superficial velocity of $2 \mathrm{~cm} \mathrm{~s}^{-1}$. The reactor was operated successively with $4 \mathrm{~min}$ of influent filling, $202 \mathrm{~min}$ of aeration, $30 \mathrm{~min}$ of settling and $4 \mathrm{~min}$ of effluent withdrawal. Effluent was discharged to yield a hydraulic retention time of $8 \mathrm{~h}$ and a COD loading rate of $3 \mathrm{~kg}$ COD $\mathrm{m}^{-3} \mathrm{~d}^{-1}$.

For phenol-fed granules, the cultivation was carried out in a column-type $(120 \mathrm{~cm}$ height; $5 \mathrm{~cm}$ diameter) reactor with a working volume of 21 . The reactor was aerated with an airflow rate of superficial velocity of $2.5 \mathrm{~mm} \mathrm{~s}^{-1}$. Synthetic wastewater containing phenolic compound similar to the one in Jiang et al. (2002) was applied to cultivate the granules at a substrate concentration of $833 \mathrm{COD}^{-1}$. The reactors operated sequentially in $4 \mathrm{~h}$ cycles. The phase duration of a typical 4-h working cycle included 2 mins of influent filling, 213-229 mins of aeration, 4-20 mins of settling, and 5 min of effluent withdrawal. The volumetric exchange ratio was of $50 \%$, and the hydraulic retention time (HRT) was $8 \mathrm{~h}$. The organic loading rate was $2.5 \mathrm{~kg}$ COD $\mathrm{m}^{-3} \mathrm{~d}^{-1}$.

The collected granules were kept fully hydrated during staining. Calcofluor white (Sigma, St. Louis, USA) was utilized to stain the $\beta$-D-glucopyranose polysaccharides (deBeer et al. 1996). The fluorescein isothiocyanate (FITC) (Molecular Probes, Carlsbad, CA, USA) is an amine reactive dye that stains proteins and other amine-containing compounds such as amino-sugars in the granules. Fluorescently labeled lectins Concanavalin A (Con A, Molecular Probes, Carlsbad, CA, USA) conjugated with tetramethylrhodamine were used to bind to $\alpha$-mannopyranosyl and $\alpha$-glucopyranosyl sugar residues. As Con A can also bind with protein and glycoconjugate groups associated with cell walls, SYTO 63 (Molecular Probes, Carlsbad, CA, USA), which is a cell-permeative nucleic acid stain, was utilized to distinguish EPS from cells.
The following quadruple staining scheme is proposed. The SYTO $63(20 \mu \mathrm{M})$ was first dripped onto the sample and was placed on a shaker table for $30 \mathrm{~min}$. Next, $0.1 \mathrm{M}$ sodium bicarbonate buffer was added to the sample to keep the amine group in non-protonated form; then, the FITC solution $\left(10 \mathrm{~g} \mathrm{l}^{-1}\right)$ was added to the sample for $1 \mathrm{~h}$ at room temperature. Subsequently, the Con A solution $\left(0.2 \mathrm{~g} \mathrm{l}^{-1}\right)$ was added to the sample and incubated for another $30 \mathrm{mins}$. Finally, calcofluor white (Sigma, St. Louis, USA) was used. After each of the four staining stages described above, the sample was washed twice by phosphate buffered saline (PBS) to remove excess stain. The stained sample was embedded in low-melting-point agar (with melting point of $75^{\circ} \mathrm{C}$ and gelling point of $38^{\circ} \mathrm{C}$ ) for observation. Some stained granules were frozen at $-20^{\circ} \mathrm{C}$ to be sectioned into $60 \mu \mathrm{m}$ sections, which were mounted onto a microscopic slide for observation.

Confocal laser scanning microscopy (CLSM; Leica TCS SP2 Confocal Spectral Microscope Imaging System, Gmbh, Germany) was employed to probe the internal structure of granules. The granule was imaged using a $\times 10$ or $\times 20$ objective and analyzed using Leika confocal software. The fluorescence of calcofluor white was detected by excitation at $400 \mathrm{~nm}$ and from the emission width at $410-480 \mathrm{~nm}$ (blue). The FITC probe was detected by excitation at $488 \mathrm{~nm}$ and emission at 500-540 $\mathrm{nm}$ (green). Excitation at $543 \mathrm{~nm}$ and emission at 550-600 $\mathrm{nm}$ (red) were used to detect Con A conjugates. The fluorescence of SYTO 63 was determined from excitation at $633 \mathrm{~nm}$ and emission at 650-700 nm. During the acquisition of CLSM images, the granule was accommodated by selecting appropriate vision field to collect the structural information for a specific part of granule. More than 550 CLSM images were sampled for a typical granule.

\section{Results}

Stained image of acetate-fed granule

Figure 1a-e shows the appearance of the outer surface and the fluorescent staining results probed at $360 \mu \mathrm{m}$ from the outer surface of a granule, respectively. The latter is a plot of the distributions of cells (SYTO 63), $\alpha$-D-glucopyranose polysaccharides (Con A), $\beta$-D-glucopyranose polysaccharides (calcofluor white), and proteins (FITC). According to the fluorescent intensity data presented in the figure, the protein formed the core, whereas, the cells and $\alpha$-Dglucopyranose polysaccharide accumulated in the outer layer of granules, consistent with those of McSwain et al. (2005). Meanwhile, the $\beta$-D-glucopyranose polysaccharide was noted to distribute throughout the interior of the granule. Restated, in contrast to McSwain's conclusion, 

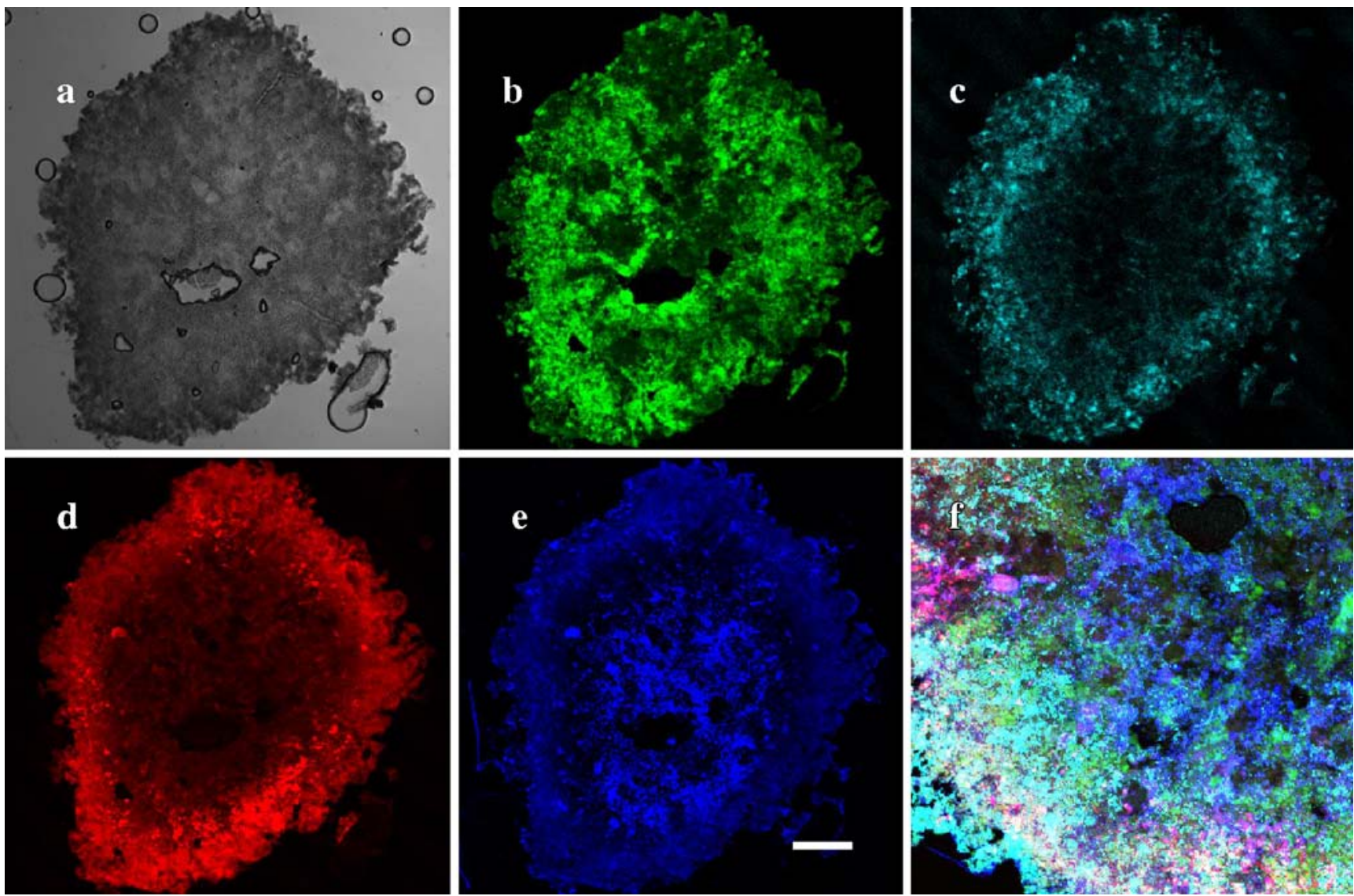

Fig. 1 Images of acetate-fed granule. Bar=200 $\mu \mathrm{m}$. a Optical microscopy photograph, b CLSM image of protein (FITC), $\mathbf{c}$ CLSM image of $\alpha$-D-glucopyranose polysaccharides (Con A), $\mathbf{d}$ CLSM image of nucleic acids (SYTO 63), e CLSM image of $\beta$-D-glucopyranose polysaccharides (calcofluor white), (f) combined image of (b)-(e) not only the protein, but also the polysaccharide (in $\beta$-Dglucopyranose form, nonetheless) was present in the core. Additionally, the finding that $\beta$-D-glucopyranose polysaccharide was not concentrated only in the outer layer but was spread throughout the granule interior, is inconsistent with the note of Wang et al. (2005), who reported that after 20 days of starvation, only a hollow shell with an intact wall of $\beta$-J-glucopyranose polysaccharide remained in the suspension.

Stained image of phenol-fed granule

Figure 2a-e present the appearance of the outer surface and the fluorescent staining results probed at $360 \mu \mathrm{m}$ from the outer surface of a phenol-fed granule, respectively. As Fig. 2a shows that the phenol-fed granule has a filamentous layer on its surface, below which, a dense layer surrounds a core (Fig. 2a). Staining results showed that the core and dense layer consisted of protein (Fig. 2b), whereas, the $\alpha$-Dglucopyranose polysaccharides, cells, and $\beta$-D-glucopyranose polysaccharides comprised the filamentous layer (Fig. 2c-e). Specifically, the $\beta$-D-glucopyranose polysac- charides were concentrated in the bottom layer, whereas, the $\alpha$-D-glucopyranose polysaccharides and cells were distributed at the outer surface of the filamentous layer. The EPS distributions in phenol-fed granules differed from those in acetate-fed granules (Fig. 1).

\section{Discussions}

Interior structure of acetate-fed granulea

Based on the staining data presented in Fig. 1, Fig. 3a shows the granule interior based on the staining scheme by McSwain et al. (cells, $\alpha$-D-glucopyranose polysaccharides, and proteins). An outer layer with concentrated cells and $\alpha$-D-glucopyranose polysaccharide clearly surrounded a noncellular protein core, just as that described by McSwain et al. (2005).

Figure $3 \mathrm{~b}$ shows a magnified view of the outer layer of the granule (Fig. 1) on a scale similar to that reported by Wang et al. (2005). Evidently, scanning one section of the surface layer of a calcofluor white-stained granule supports 

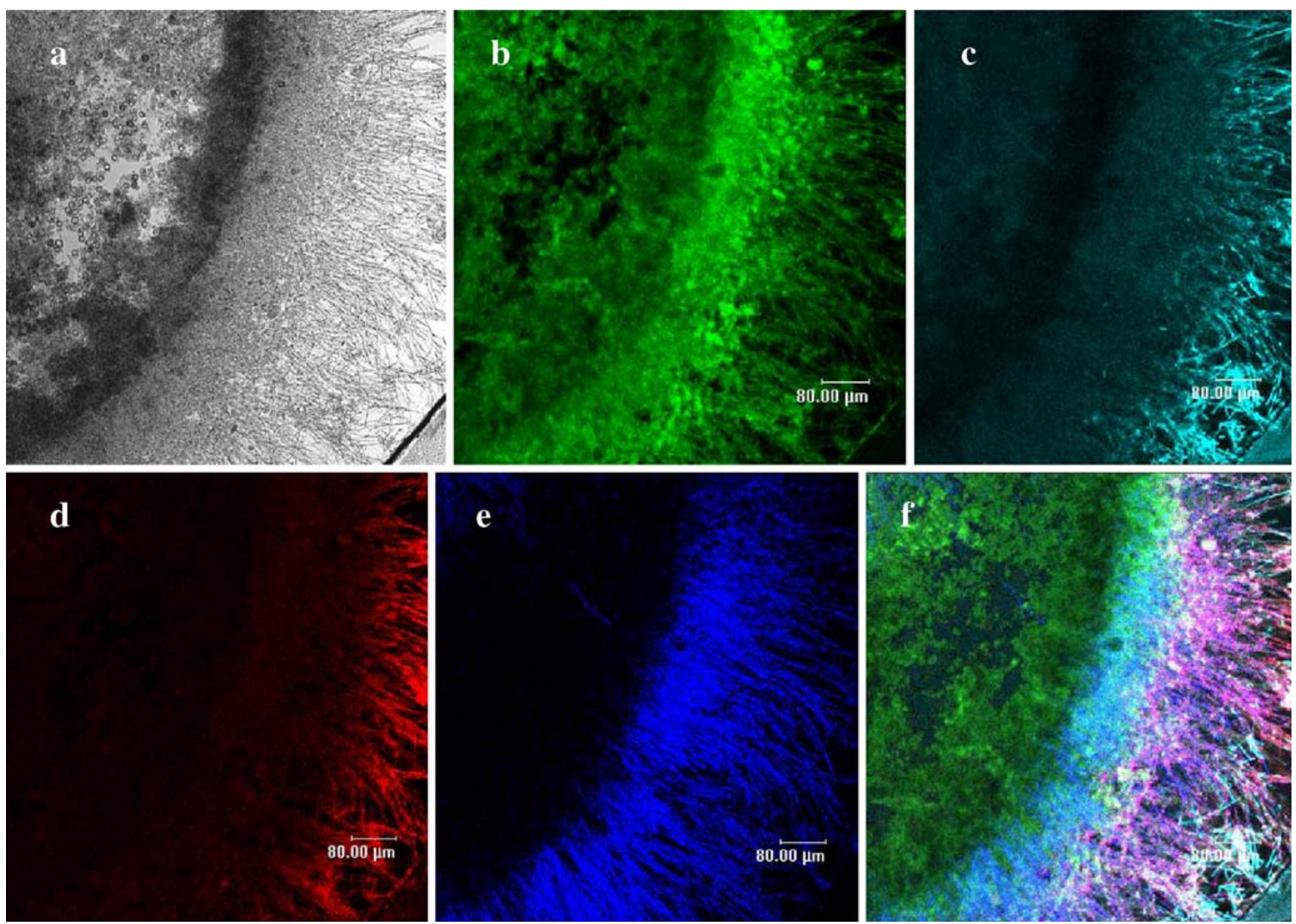

Fig. 2 Images of phenol-fed granule. Bar=80 $\mu \mathrm{m}$. a Optical microscopy photograph, b CLSM image of protein (FITC), $\mathbf{c}$ CLSM image of $\alpha$-D-glucopyranose polysaccharides (Con A), $\mathbf{d}$ CLSM image

of nucleic acids (SYTO 63), e CLSM image of $\beta$-D-glucopyranose polysaccharides (calcofluor white), $\mathbf{f}$ combined image of (b)-(e)

the conclusion that $\beta$-D-glucopyranose polysaccharide was restricted to the outer edge of the granule only; however, the cross-sectional view revealed a relatively uniform distribution of $\beta$-D-glucopyranose polysaccharide in the granule interior.

Fig. 3 CLSM images of acetatefed granule. a Combined image based on McSwain's staining scheme (FITC+Con A+ SYTO 63); b magnified view of CLSM image based on Wang's scheme (calcofluor white); $b a r=80 \mu \mathrm{m}$
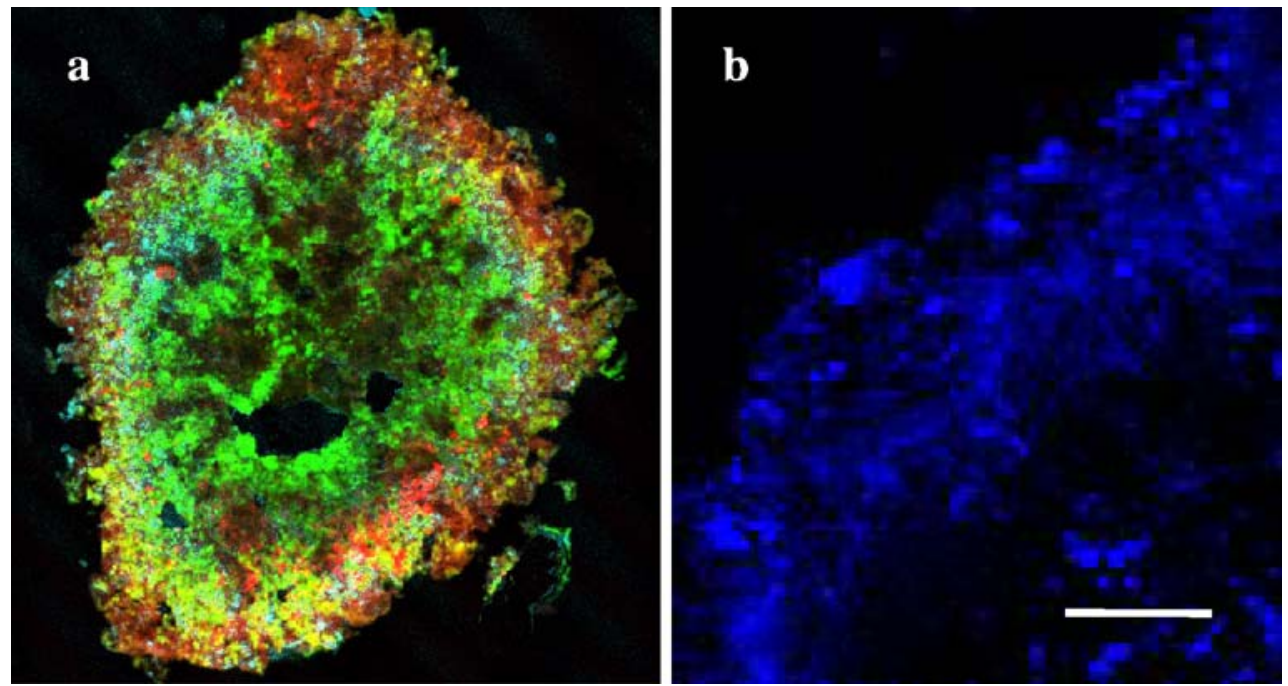
quadruple staining image combining Figs. 2b-e. The acetate-fed granule interior can be approximated by a twolayer structure, with the outer layer constituted by all four analyzed components (proteins, $\alpha$ - and $\beta$-D-glucopyranose polysaccharides, and cells) and a core primarily of protein and $\beta$-D-glucopyranose polysaccharides (Fig. 1f). Cells were crowded in an outer layer of thickness of roughly $250 \mu \mathrm{m}$. Therefore, the model of acetate-fed granule should
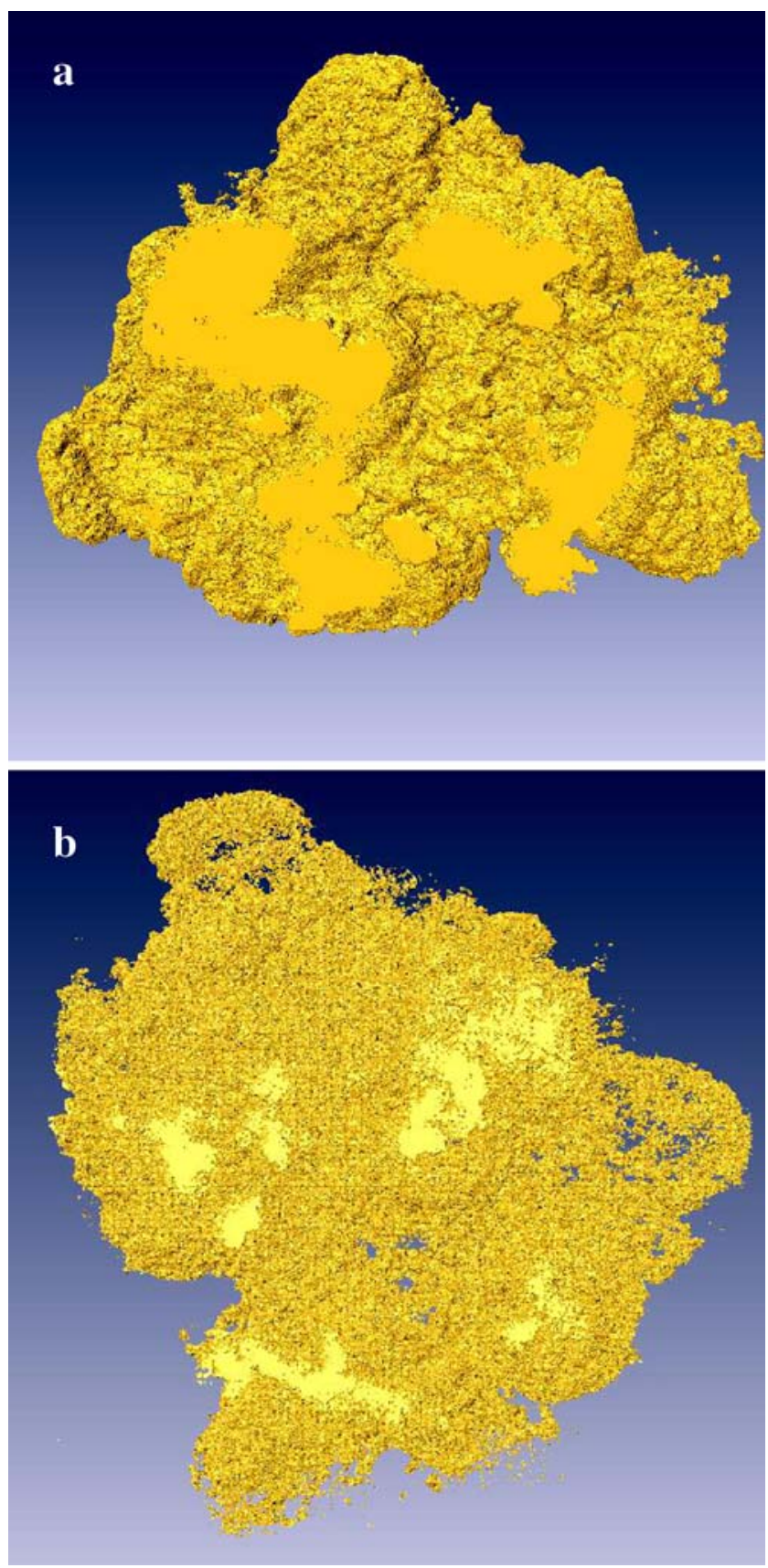

Fig. 4 Three-dimensional re-constructed images for components in acetate-fed granules. a FITC-stained proteins in granule's core. b SYTO 63-stained nucleic acids at surface layer of granules surrounding the inner core have at least a biologically active outer layer covering a heterogeneous polysaccharide-protein core (with holes).

A series of CLSM images were utilized to reconstruct the interior structure of granules using the following image processing scheme (Chu and Lee 2004). Otsu's scheme was applied to determine the threshold values for each CLSM image; then, the threshold value was applied to bilevel each image. A series of bileveled images were then obtained. Next, the three-dimensional visualization and modeling software, Amira 3.0 (TGS, USA), was employed to
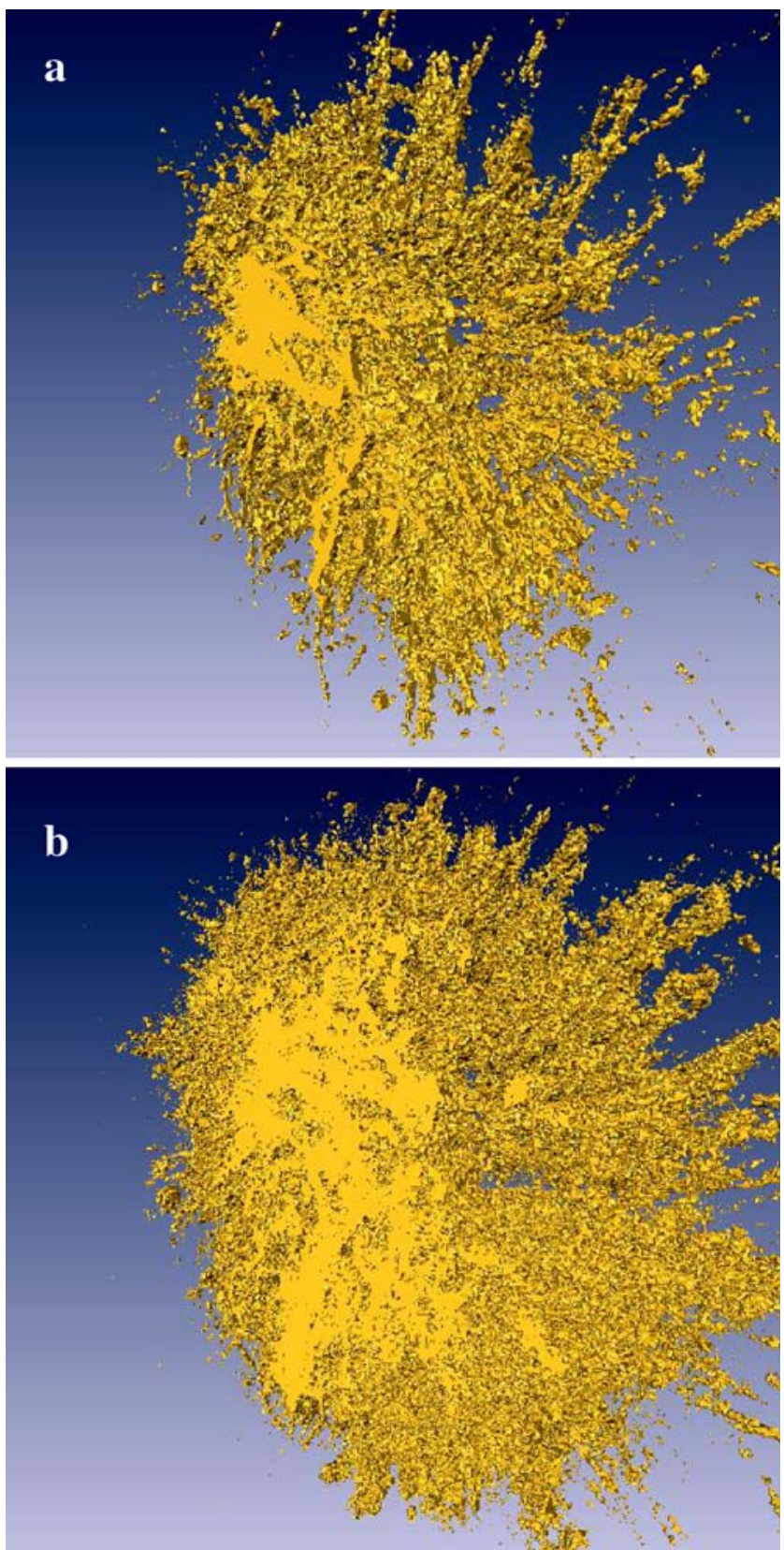

Fig. 5 Three-dimensional re-constructed images for components in phenol-fed granules. a FITC-stained proteins in granule's core. b SYTO 63-stained nucleic acids at surface layer of granules surrounding the inner core 
reconstruct the bileveled images as a polygonal surface model. Boundaries in the binary images are classified based on connectivity and whether they lie within the object or its complement. The connectivity of neighboring pixels is set to four for edge detection. Once boundaries were sketched, the isosurfaces were established to demonstrate the threedimensional shape of the object.

Figure 4a presents the three-dimensional distribution of proteins (stained by FITC) in acetate-fed granules. Although it has a porous interior (Fig. 1), the protein core has a dense shell layer with a rugged surface. This shell layer generates a strong resistance to substrate diffusion and minimizes possible advective flow through the granule. The cells (stained by SYTO 63) were primarily accumulated at the outer rim layer of the acetate-fed granule (Fig. 1d). However, unlike proteins (Fig. 4b), the cells gather in clusters and had not formed a continuous layer. Substrates can easily penetrate the cell layer and reach individual cells.

Figure $5 \mathrm{a}$ and $\mathrm{b}$ show the three-dimensional distributions of proteins and cells close to surface of the phenol-fed granules, respectively; the detailed structure of the filamentous layer (Fig. 2) was clearly demonstrated. With extended structure, filamentous layer cells were fully exposed to the surrounding phenol-containing water. A strong advective flow through the cell layer may exist, thereby, minimizing mass transfer limitation. Together with the chemical and hydrodynamic surrounding, such as nutrient and oxygen supply and hydrodynamic shear force, the intra-granule transport process can be detailed with the explored structural information provided herein.

\section{References}

Beun JJ, Hendriks A, Van Loosdrecht MCM, Morgenroth E, Wilderer PA, Heijnen JJ (1999) Aerobic granulation in a sequencing batch reactor. Water Res 33:2283-2290

Bockelmann U, Manz W, Neu TR, Szewzyk U (2002) Investigation of lotic microbial aggregates by a combined technique of fluorescent in situ hybridization and lectin-binding analysis. J Microbiol Methods 49:75-87

Boessmann M, Neu TR, Horn H, Hempel DC (2004) Growth, structure and oxygen penetration in particle supported autotrophic biofilms. Water Sci Technol 49(11-12):371-377

Cerca N, Martins S, Sillankorva S, Jefferson KK, Pier GB, Oliveira R, Azeredo J (2005) Effects of growth in the presence of subinhibitory concentrations of dicloxacillin on Staphylococcus epidermidis and Staphylococcus haemolyticus biofilms. Appl Environ Microbiol 71:8677-8682

Chiu ZC, Chen MY, Lee DJ, Tay STL, Tay JH, Show KY (2006) Diffusivity of oxygen of aerobic granules. Biotechnol Bioeng (in press)

Chu CP, Lee DJ (2004) Multiscale structures of biological flocs. Chem Eng Sci 59:1875-1883
deBeer D, Flaharty VO, Thaveesri J, Lens P, Verstraete W (1996) Distribution of extracellular polysaccharides and flotation of anaerobic sludge. Appl Microbiol Biotechnol 46:197-201

Jiang HL, Tay JH, Tay STL (2002) Aggregation of immobilized activated sludge cells into aerobically grown microbial granules for the aerobic biodegradation of phenol. Letters Appl Microbiol 35:439-445

Lawrence JR, Swerhone GDW, Leppard GG, Araki T, Zhang X, West MM, Hitchcck AP (2003) Scanning transmission X-ray, laser scanning, and transmission electron microscopy mapping of the exopolymeric matrix of microbial biofilms. Appl Environ Microbiol 69:5543-5554

Lawrence JR, Cheier MR, Roy R, Beaumier D, Fortin N, Swerhone GDW, Neu TR, Greer CW (2004) Microscale and molecular assessment of impacts of nickel, nutrients, and oxygen level on structure and function of river biofilm communities. Appl Environ Microbiol 70:4326-4339

Lawrence JR, Swerhone GDW, Wassenaar LI, Neu TR (2005) Effects of selected pharmaceuticals on riverine biofilm communities. Can J Microbiol 51:655-669

Liu Y, Liu QS (2006) Causes and control of filamentous growth in aerobic granular sludge sequencing batch reactors. Biotechnol Adv 24:115-127

Liu Y, Tay JH (2004) State of the art of biogranulation technology for wastewater treatment. Biotechnol Adv 22:533-563

McSwain BS, Irvine RL, Hausner M, Wilderer PA (2005) Composition and distribution of extracellular polymeric substances in aerobic flocs and granular sludge. Appl Environ Microbiol 71:1051-1057

Morgenroth E, Sherden T, Van Loosdrecht MCM, Heijnen JJ, Wilderer PA (1997) Aerobic granular sludge in a sequencing batch reactor. Water Res 31:3191-3194

Neu TR, Swerhone GDW, Lawrence JR (2001) Assessment of lectinbinding analysis for in situ detection of glycoconjugates in biofilm systems. Microbiol 147:299-313

Neu TR, Woelfl S, Lawrence JR (2004) Three-dimensional differentiation of photo-autotrophic biofilm constituents by multi-channel laser scanning microscopy (single-photon and two-photon excitation). J Microbiol Methods 56:161-172

Peng DC, Bernet N, Delgenes JP, Moletta R (1999) Aerobic granular sludge-a case report. Water Res 33:890-893

Schmid M, Thill A, Purkhold U, Walcher M, Bottero JY, Ginestet P, Nielsen PH, Wuertz S, Wagner M (2003) Characterization of activated sludge flocs by confocal laser scanning microscopy and image analysis. Water Res 37:2043-2052

Staudt C, Horn H, Hempel DC, Neu TR (2004) Volumetric measurements of bacterial cells and extracellular polymeric substance glycoconjugates in biofilms. Biotechnol Bioeng 88:585-592

Strathmann M, Wingender J, Flemming HC (2002) Application of fluorescently labelled lectins for the visualization and biochemical characterization of polysaccharides in biofilms of Pseudomonas aeruginosa. J Microbiol Methods 50:237-248

Tay JH, Liu QS, Liu Y (2001a) Microscopic observation of aerobic granulation in sequential aerobic sludge blanket reactor. J Appl Microbiol 91:168-175

Tay JH, Lin QS, Liu Y (2001b) The role of cellular polysaccharide in the formation and stability of aerobic granules. Letters Appl Microbiol 33:222-226

Wang ZW, Liu Y, Tay JH (2005) Distribution of EPS and cell surface hydrophobicity in aerobic granules. Appl Microbiol Biotechnol 69:469-473

Yang SF, Tay JH, Liu Y (2003) A novel granular sludge sequencing batch reactor for removal of organic and nitrogen from wastewater. J Biotechnol 106:77-86 